\title{
An Overview of the Impacts of Global Climate Change on Farmland in Turkey
}

\author{
Ayse Ozcan and Eric Strauss
}

\begin{abstract}
Turkey is a country located in a semi-arid climate. As a result of worldwide climate change, dry land farming will drift to the north, decreasing agricultural productivity. Currently in Turkey agriculture generates $7.2 \%$ of GDP, $11.3 \%$ of exports, $21.5 \%$ of employment and constitutes $34 \%$ of the land area. The amount of agricultural land has decreased $15 \%$ since 2000 . Future projections for the country show an increase in temperature and a reduction in precipitation. This affects the type of crops grown and the use of water resources for irrigation and power production. Government policy must be specifically designed to positively deal with these specific impacts.
\end{abstract}

Index Terms-Climate change, agriculture, water resources, GDP, Turkey.

\section{INTRODUCTION}

It is expected that by the year 2030, the ratio of $\mathrm{CO}_{2}$ in the atmosphere would increase about twice if we compare the period before the industrial revolution, global temperature is expected to rise between 2 to 5 degrees [1]. Signs of climate change such as temperature increases, sea-level rise, atmospheric events and significant changes occured with heavy rainfall affect the ecological balance in the world. It is also estimated that there are many environmental problems caused by the increase in world population and cause negative impacts on such issues as food security, water, energy, biodiversity and soil erosion depending on the climate change will be felt more and more.

From 1901 to 2005, Canada, Rusia, Atlantic Ocean, Indian Ocean, and Brazil are seen as the regions come to fore with 1,4-1,7 degrees temperature rise in the world. Data has been monitored that show the Atlantic Ocean, Indian Ocean and a large part of Australia have a temperature rise of between 1.1-1.4 degrees [2].

Agriculture is the most vulnerable sector that might be affected from climate changes in the economy. Although many technological and biological innovations have been developed in agriculture, it is still dependent on climate conditions. Climate change may impact agriculture in multiple ways. Changes in temperature and precipitation may affect the timing and length of growing seasons, as well as yields. These climatic changes may also affect water availability for agriculture. Increasing carbon dioxide concentrations, meanwhile, will have a positive effect on water use efficiency leading to higher yields for certain crops. Changes in climate variability, in particular changes in the intensity and/or frequency of floods, drought and storms, are also expected to significantly affect agricultural production. Regional yields are projected to increase up to $3^{\circ} \mathrm{C}$ of warming in mid to high latitudes, while they are expected to decline in low latitudes for any increase in temperature [3], [4]. These effects can be summarized as follows:

- Herbal product efficiency and production cost: Agricultural loses increase when drought and excessive rainfall occur.

- The suitability of the soil for agricultural production: Soil productivity losses will occur with an increase in temperature. Temperature increases the microbial composition of soil and so it affects the soil nutrient elements as negative.

- Irrigation water supply.

The Intergovernmental Panel on Climate Change (IPCC) 2007 Report [5] projects that the climate could warm by as much as $5^{\circ} \mathrm{C}$ over the next 100 years, and estimates that we have already seen a warming of about $0,7^{\circ} \mathrm{C}$ since 1900 Agriculture will be the most affected sector from climate change, because it mostly depends on climate.

In this study the results of impact assessment of climate change on Turkish agriculture are discussed. The conclusion of this paper is that climate change has affected crop yields negatively in Turkish agriculture.

\section{Methodology}

As this study is based on a literature review, it includes the studies on the general sources discussing the impacts of climate change on farmland and farming policies in Turkey carried out by several private and state institutions. Internet sources, books and articles published abroad on these topics have also been used. The research methodology consists of interpreting previous studies, evaluating and synthesizing sources, identifying the impacts of climate change on farmland in Turkey. By this way, it has aimed to discuss the results of impact assessment of climate change on Turkish agriculture sector. The main method adopted has to evaluate, synthesize and establish relationships among the works form the relevant literature.

\section{A GLOBAL LOOK \\ II. A GLOBALLOOK}

Ayse Ozcan is with Giresun University, Faculty of Economics and Administrative Sciences, Giresun, Turkey (e-mail: ayoz_61@ @otmail.com)

Eric Strauss is with Michigan State University, School of Planning, Design and Construction, East Lansing, MI, USA (e-mail: strausse@msu.edu).
According to FAO data, in 2010, there were approximately 3.2 billion hectares of pasture and 1.5 billion hectares of cropland globally. Of course, the extent and proportion of 
total land area vary greatly across regions. Arable land per capita has decreased by $14.3 \%$ in developed countries and $40 \%$ in developing countries. Agricultural land per capita is 0,23 hectares and this value will decline by $15 \%$ in 2050 [6]-[8].

Farmland in the world covers an important area in Australia, China, Brazil, the United States and Saudi Arabia. Countries located in very arid climate zone (such as Algeria, Libya, Egypt, Saudi Arabia, Niger) and countries located in arid climate zone (such as Australia, Chile, South Africa, Iran, Kazakhstan, China) will be affected primarily by climate change. It is assumed that Turkey as a country located in semi-arid climate zone will also be affected primarily by climate change.

Agricultural production shortages and surpluses arising as a result of climate change greatly affect the economic balance. For example, the reduction of production could lead to increase in product prices. Therefore, consumers pay a higher price that can lead to an increase in imports and a decline in exports. It will have an impact on human health, livelihood assets, food production and distribution channels, as well as changing purchasing power and market flows. Its impacts will be both short term, resulting from more frequent and more intense extreme weather events as well as long term causing changing temperatures and precipitation patterns (see Fig.1).

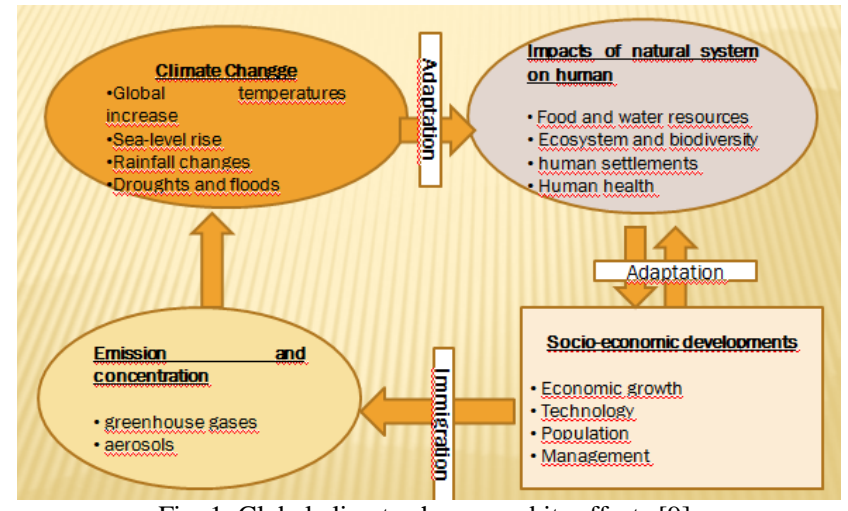

Fig. 1. Global climate change and its effects [9].

According to the most of the scientific studies on climate changes, it is estimated that dryland farming areas and cereals grown areas of the world will be shifted towards the North. In addition to this increase, the geographic shift is expected to decrease from $10 \%$ to $50 \%$ in yield [10]-[14]. Reference [11] examined climate change impact on world food supply. They projected global yield losses amounting to $16 \%$ for wheat and $20 \%$ for corn with a variation of $3 \%$ and $51 \%$ across countries Reference [14] projects that the regional crop production impacts of climate change will be geographically uneven. Their findings show that cereal production increased in colder regions of Latin America (as 3.7\%-14.9) and Former Soviet Union (as $4.9 \%-7 \%$ ), but decreased production in all the other currently warmer and drier regions. Reference [10] draws together evidence from the IPCC and show Turkish agriculture may well be vulnerable.

While it is expected to decrease in crop productivity in the future due to climate change in some parts of the world according to various projections, some regions are expected to increase in productivity. It is predicted that agricultural crop production will be reduce from $15 \%$ to $\% 25$ in Turkey (see Fig. 2 and Fig. 3) [4], [13].

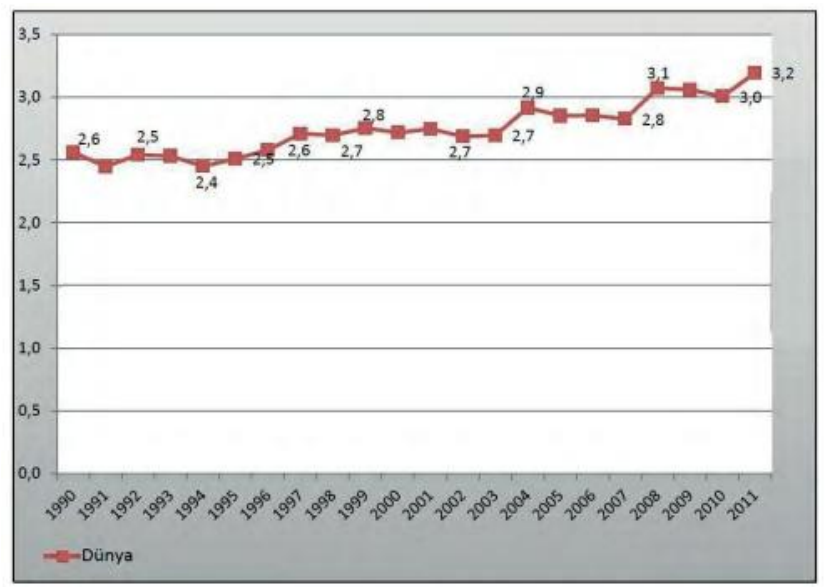

Fig. 2. World wheat production (ton/hectare), 1990-2011 [15]

According to the USDA data in the period between 2010-2011 wheat production decreased in US, Alaska and Iran. Canada, Russia, China, Kazakhstan and Australia have shown an increase in wheat production [16] (see Fig.3).

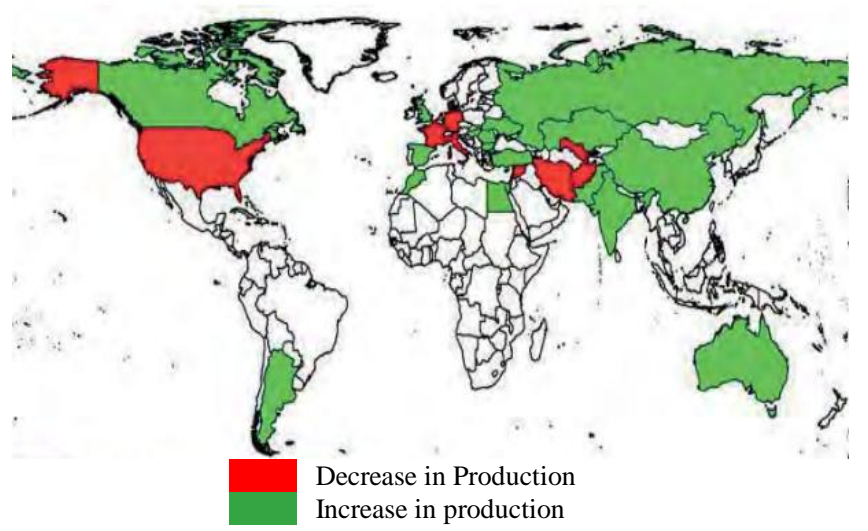

Fig. 3. Wheat production by country (2010-2011) [16].

\section{Climate Change AND Turkey}

\section{A. General Situation of Agricultural Land in Turkey}

$37 \%$ of Turkey's population lives in rural areas. As of 2013, the share of Turkey's agriculture sector in GDP is 7.2\% while agricultural employment is $21.5 \%$ in 2014. As of 2011 Turkey's total exports are 134.9 billion dollars and agricultural exports are 15.3 billion dollars. The share of agriculture sector including agriculture and forestry is 11.3 percent of total exports. The share of agricultural imports is 7.3 percent with a total value of 17.6 billion dollars in 2011 [17]-[20].

Agricultural areas constitute approximately $35 \%$ of the land of Turkey. Forest areas cover $26 \%$ of land and $16 \%$ of the land consists of meadow and pasture areas. As of 2010, the land used for agriculture is 24.3 million hectares, and about $20 \%$ of this area is dedicated to irrigated agriculture and the remaining $80 \%$ is used for dryland farming. Agricultural areas have declined steadily between 1990-2012 in Turkey.

As shown in Table I and Table II, the cultivated land areas making up the majority of agricultural land have been steadily decreasing since 2000. Sown field areas have shown a decrease in the rate of 14.3 percent. Fallow areas have 
decreased since 2000. From 2000 to 2012 sown and fallow areas have been decreasing without fluctations.

TABLE I: AGRICULTURAL AREAS IN TURKEY (1990-2002) [21]

\begin{tabular}{|c|c|c|c|c|c|c|}
\hline Area Type & 1990 (1000 ha) & $\begin{array}{c}1990 \\
(\%)\end{array}$ & $\begin{array}{c}2000 \\
(1000 \text { ha })\end{array}$ & $\begin{array}{c}2000 \\
(\%)\end{array}$ & 2002 (1000 ha) & $\begin{array}{c}2002 \\
(\%)\end{array}$ \\
\hline Cultivated Area & 18,868 & 67.7 & 18,207 & 69.0 & 18,123 & 68.2 \\
\hline Fallow & 5,324 & 19.1 & 4,826 & 18.3 & 5,040 & 19.0 \\
\hline $\begin{array}{l}\text { Area of Vegetable } \\
\text { Gardens }\end{array}$ & 635 & 2.3 & 793 & 3.0 & 831 & 3.1 \\
\hline Vineyards & 580 & 2.1 & 535 & 2.0 & 530 & 2.0 \\
\hline Orchards & 1,583 & 5.7 & 1,418 & 5.4 & 1,435 & 5.4 \\
\hline Olive Garden & 866 & 3.1 & 600 & 2.3 & 620 & 2.3 \\
\hline Total & 27,856 & 100 & 26,739 & 100 & 26,579 & 100 \\
\hline
\end{tabular}

TABLE II: AGRICULTURAL AREAS IN TURKEY (1990-2002) [21]

\begin{tabular}{|c|c|c|c|c|c|c|}
\hline Area Type & $\begin{array}{c}\mathbf{2 0 0 6}(\mathbf{1 0 0 0} \\
\text { ha) }\end{array}$ & $\begin{array}{c}\mathbf{2 0 0 6} \\
(\mathbf{\%})\end{array}$ & $\begin{array}{c}\mathbf{2 0 0 9} \\
(\mathbf{1 0 0 0} \mathbf{h a})\end{array}$ & $\begin{array}{c}\mathbf{2 0 0 9} \\
(\mathbf{\%})\end{array}$ & $\begin{array}{c}\mathbf{2 0 1 0}(\mathbf{1 0 0 0} \mathbf{h a}) \\
\mathbf{2 0 1 0} \\
(\mathbf{\%})\end{array}$ \\
\hline Cultivated Area & 17,440 & 67.9 & 16,217 & 66.8 & 16,333 & 67.5 \\
\hline Fallow & 4,691 & 18.1 & 4,323 & 17.8 & 4,249 & 17.1 \\
\hline Area of Vegetable Gardens & 850 & 3.0 & 811 & 3.1 & 802 & 3.0 \\
\hline Vineyards & 513 & 2.0 & 479 & 2.0 & 478 & 2.0 \\
\hline Orchards & 1,670 & 6.3 & 1,686 & 6.9 & 1,748 & 7.2 \\
\hline Olive Garden & 712 & 2.8 & 778 & 3.2 & 784 & 3.2 \\
\hline Total & 25,876 & 100 & 24,294 & 100 & 24,394 & 100 \\
\hline
\end{tabular}

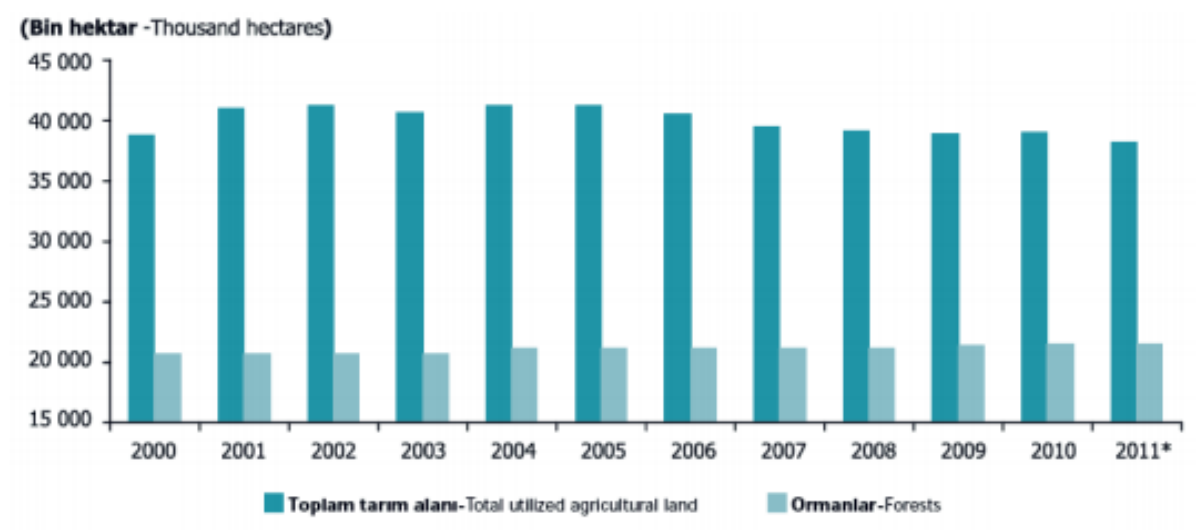

Graph 1. Agriculture and forest areas in Turkey (2000-2012) [21].

The Turkish government has officially defined the types of agricultural land. The "Regulation for the implementations of the Law on soil protection and land use" dated December 15, 2005 has reclassified farmland areas and has established the legal framework about farmland classification. According to the Regulation farmland types include prime farmland, custom sewn product farmland, woodland, marginal farmland, protected farmland, greenhouses and other farmland plots that consist of 27, 510,751 hectares [22] (see Table III).

Changes in the use of farmland in Turkey were examined together with population growth. The data shows significant increases in the amount of land opened for agriculture. In 1928, 6.6 million hectares of agriculture were cultivated and there were 25.3 million hectares cultivated in 1950. The figure at the end of the 1980s reached the level of about 28 million hectares [23]. However farmland areas have been started to shrink since the beginning of the 1990s (see Table IV - Table VI). The causes of this decrease as follows: farmland use allocation for non-farm purposes, the small business land in the agriculture sector, non-farmland areas, incorrect agricultural activities, incorrect land use, and of course some extreme events depending on climate change.

Approximately 21.4 million hectares of the land used for agricultural production is total arable land, and 3 million hectares of the area covered with orchards and olive gardens. Total land under permanent meadows and pastures is about
14,6 million hectares. Therefore, as of 2014 the total land area used for agricultural purposes is 37.7 million hectares [22], [26]. According to the data given above, as of 2011 the total land used for agricultural purposes is 38.2 million hectares. In addition to this, as land usage amounts has varied from year to year, 18-22 percent of the cultivated area, which constitutes 4-5 million hectares of arable land, has been left as fallow area.

TABLE III: TURKEY's TOTAL LAND WITHIN THE SCOPE OF FARMLAND CLASSIFICATION (HECTARES) [22]

\begin{tabular}{|c|c|c|c|}
\hline $\begin{array}{c}\text { Prime } \\
\text { Farmland }\end{array}$ & $\begin{array}{c}\text { Marginal } \\
\text { Farmland }\end{array}$ & Woodland & $\begin{array}{c}\text { Custom } \\
\text { Sewn } \\
\text { Product } \\
\text { Farmland }\end{array}$ \\
\hline $11,613,090$ & $12,135,961$ & $2,883,105$ & 78,594 \\
\hline
\end{tabular}

TABLE IV: FARMLAND USE TYPeS By YEAR (1000 HeCtARES) [15], [24], [25]

\begin{tabular}{|c|c|c|}
\hline Year & $\begin{array}{c}\text { Total Farmland } \\
(\mathbf{G}=\mathbf{E}+\mathbf{F})\end{array}$ & $\begin{array}{c}\text { Total Arable Land and } \\
\text { Land Under Permanent } \\
\text { Crops (E=C+D) }\end{array}$ \\
\hline $\mathbf{1 9 9 0}$ & 42,033 & 27,856 \\
\hline $\mathbf{1 9 9 5} *$ & 39,212 & 26,834 \\
\hline $\mathbf{2 0 0 0}$ & 38,757 & 25,586 \\
\hline $\mathbf{2 0 0 5}$ & 41,223 & 25,657 \\
\hline $\mathbf{2 0 1 1} * *$ & 38,231 & 22,800 \\
\hline $\mathbf{2 0 1 2}$ & 37,568 & 22,951 \\
\hline $\mathbf{2 0 1 3}$ & 37,640 & 23,023 \\
\hline $\mathbf{2 0 1 4} * * *$ & 37,752 & 23,135 \\
\hline
\end{tabular}


TABLE V: TOTAL ARABLE LAND BY YEAR (1000 HECTARES) [15], [24], [25]

\begin{tabular}{|c|c|c|c|}
\hline Year & Sown Area (A) & $\begin{array}{c}\text { Fallow } \\
\text { Land (B) }\end{array}$ & $\begin{array}{c}\text { Total } \\
(\mathbf{C + A + B )}\end{array}$ \\
\hline $\mathbf{1 9 9 0}$ & 18,868 & 5,324 & 24,827 \\
\hline $\mathbf{1 9 9 5}^{*}$ & 18,464 & 5,124 & 24,373 \\
\hline $\mathbf{2 0 0 0}$ & 18,207 & 4,826 & 23,033 \\
\hline $\mathbf{2 0 0 5}$ & 18,005 & 4,876 & 22,881 \\
\hline $\mathbf{2 0 1 1} * *$ & 15,692 & 4,017 & 19,709 \\
\hline $\mathbf{2 0 1 2}$ & 15,464 & 4,286 & 19,750 \\
\hline $\mathbf{2 0 1 3}$ & 15,613 & 4,188 & 19,791 \\
\hline $\mathbf{2 0 1 4} * * *$ & 15,789 & 4,108 & 19,897 \\
\hline
\end{tabular}

TABLE VI: Total LAND Under PeRmanent AgRiculture by Year (1000 HECTARES) [15], [24], [25]

\begin{tabular}{|c|c|c|}
\hline Year & $\begin{array}{c}\text { Total Land Under } \\
\text { Permanent Crops } \\
\text { (D) }\end{array}$ & $\begin{array}{c}\text { Land Under } \\
\text { Permanent Meadows } \\
\text { and Pastures (F) }\end{array}$ \\
\hline $\mathbf{1 9 9 0}$ & 3,029 & 14,177 \\
\hline $\mathbf{1 9 9 5} *$ & 2,461 & 12,738 \\
\hline $\mathbf{2 0 0 0}$ & 2,553 & 12,738 \\
\hline $\mathbf{2 0 0 5}$ & 2,776 & 14,617 \\
\hline $\mathbf{2 0 1 1} * *$ & 3,091 & 14,617 \\
\hline $\mathbf{2 0 1 2}$ & 3,201 & 14,617 \\
\hline $\mathbf{2 0 1 3}$ & 3,232 & 14,617 \\
\hline $\mathbf{2 0 1 4} * * *$ & 3,238 & 14,617 \\
\hline
\end{tabular}

Note: Figures may not be equal to total due to rounding off.

*Data are grouped according to Statistical Classification of Products By Activity in European Economic Community (CPA 2002) since 1995.

Since 1995, only areas covered with fruit and olive are given, it is not included areas covered by scattered trees.

**Data have been compiled since 2011.

*** Data are provisional.

According to the results of agricultural land use ability scheme (AKKS in Turkish) it is seen that the share of land situated in the first four classes is $\% 34,1$ in total. Thus it can be understood that in 2014 Turkey has approximately 26,5 million hectares (total arable land and land under permanent crops-23,135 million hectares) including embroidered agriculture and permanent crops production. In contrast, agricultural production was made on a wide range of land -around 27,9 million hectares in total- between the years 1990-2011 [27]. The data indicates a loss of one million hectares of farmland within the last five years.

There are no reliable data relating to the amount of the missing part of the farmlands in Turkey. According to data of General Directorate for Rural Services (former), 17.043.482.000 $\mathrm{m}^{2}$ farmland has been destroyed in between 1985-2003. The area first and second class non-agricultural lands are 1.781.843.000 $\mathrm{m}^{2}$ [28]. After the General Directorate for Rural Services, detailed institutional inventories have not been performed for farmlands. Therefore contemporary data are unknown. According to Reference 25, 4.13.099.000 $\mathrm{m}^{2}$ farmland has been destroyed in between 1991-2001. That is the important problem that how to configure an effective agricultural policy based upon these outdated data of Turkey.

As of 2010, Turkey's total agricultural land is 24.21 million hectares and total cultivated area is 21.35 million hectares. Intensive farming is being done fully irrigated over 5.4 million hectares of land (22\% of agricultural land) [20]. According to Reference 25 data $24.1 \%$ of total land is irrigated land while $75 \%$ of total land is not irrigated.

In Turkey arid and semi-humid land areas are located in a large portion of the Central Anatolia and Southeastern Anatolia Region and some parts of Central and Eastern Mediterranean Region and in the some east parts and west parts of Eastern Anatolia. Semi-arid climate is dominant especially in Igdir and Konya located in central and eastern Anatolia, and the total average annual precipitation is less than $400 \mathrm{~mm}$ for these regions. Turkey has arid areas prone to desertification especially in the terrestrial inner and Eastern Anatolia and Southeastern Regions [29].

\section{B. General Situation of Agricultural Land in Turkey}

Turkey lies in a region that is highly vulnerable to climate change. The future climate change projections agree on an increase in temperatures throughout the country as well as a reduction in precipitation in the southern half of the country. The IPCC Reports (for 4th and 5th Reports) and other national and international scientific modeling studies demonstrate that Turkey in near future will get hotter, more arid and unstable in terms of precipitation patterns. In the case of increases in the global temperature of up-to $2^{\circ} \mathrm{C}$; the expected impacts in the Mediterranean Basin which includes Turkey show the extent to which measures taken against the impacts of climate change need to be programmed [4], [30], [31].

In Reference 4 it is indicated that a $1{ }^{\circ} \mathrm{C}-2^{\circ} \mathrm{C}$ increase in temperatures in the Mediterranean Basin would be observed. This suggests that aridity will be felt in an even wider area, and heat waves and the number of very hot days will increase especially in inland regions. For Turkey, on the other hand, the average increase in temperatures is estimated to be around $2.5^{\circ} \mathrm{C}-4^{\circ} \mathrm{C}$, reaching up to $5^{\circ} \mathrm{C}$ in inner regions and up to $4^{\circ} \mathrm{C}$ in the Aegean and Eastern Anatolia.

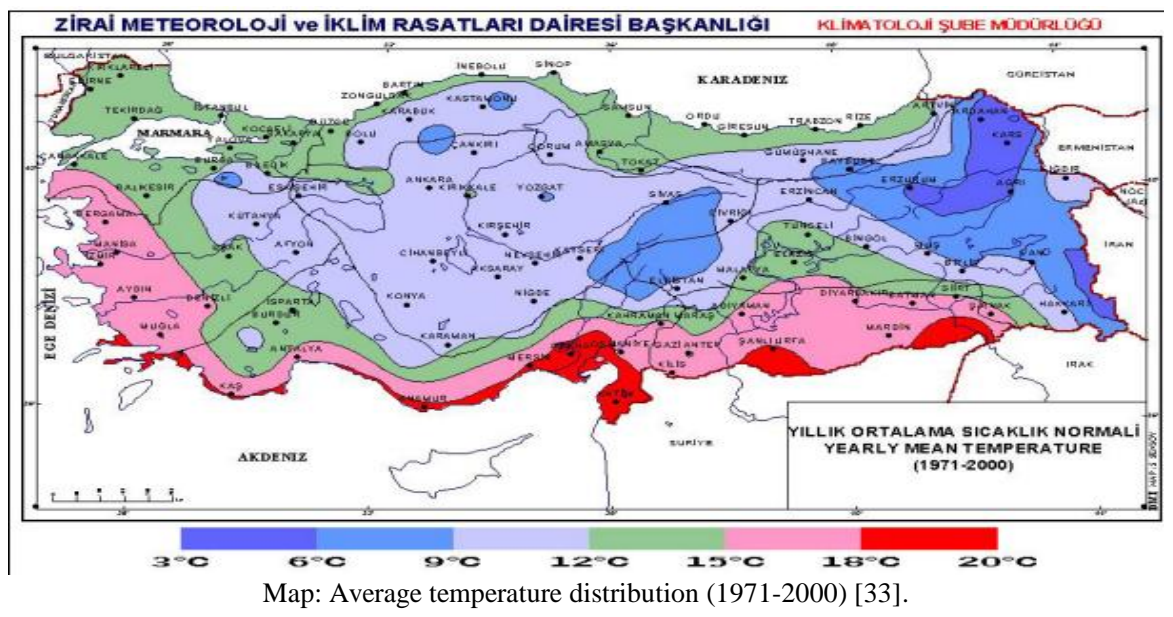


It is inevitable that for these changes to impact the country's water resources negatively by reducing the water potential in the southern basins. The projections that were based on the high emissions scenarios indicate water potential reductions up to $37 \%$ in the Mediterranean basins, up to $70 \%$ in Konya basin and up to $10 \%$ in the Euphrates and Tigris basins by the mid twenty first century [4], [32]. The decline in the water resources will, first and foremost, influence the agriculture, animal husbandry and related sectors. Hydroelectric energy production is another sector that will be negatively affected by the water potential reduction in Turkey In addition, Turkey will be subjected to more droughts, heat waves and forest fires. The wider prevalence of Mediterranean climate in Turkey in the future (together with the expansion of warm summer period) will have positive effects in terms of both human life and tourism

The most sensitive and weak areas against heat and cold waves in Turkey are Central Anatolia and Eastern Anatolia region. The weakest and most sensitive areas in terms of Turkey's precipitation climatology are Central Anatolia Region, inner Aegean and Eastern Anatolia Region. Central Anatolia Region is also quite sensitive to temperature. All action plans and strategies for adaptation to climate change should be prepared in accordance with these data.

TABLE VII: TURKEY'S TOP TEN WARMEST YEAR [34]

\begin{tabular}{|c|c|c|c|}
\hline Year & $\begin{array}{c}\text { Average } \\
\text { Temperature }\end{array}$ & $\begin{array}{c}\text { Normal } \\
\text { Temperature } \\
\text { S(1971-2000) }\end{array}$ & $\begin{array}{c}\text { Differenc } \\
\mathbf{e} \\
{ }^{\circ} \mathbf{C}\end{array}$ \\
\hline $\mathbf{2 0 1 0}$ & 15.2 & 12.81 & 2.39 \\
\hline $\mathbf{2 0 0 1}$ & 14.22 & 12.81 & 1.41 \\
\hline $\mathbf{1 9 9 9}$ & 14.10 & 12.81 & 1.29 \\
\hline $\mathbf{1 9 9 8}$ & 13.80 & 12.81 & 0.99 \\
\hline $\mathbf{2 0 0 7}$ & 13.75 & 12.81 & 0.94 \\
\hline $\mathbf{2 0 0 9}$ & 13.70 & 12.81 & 0.89 \\
\hline $\mathbf{2 0 0 5}$ & 13.68 & 12.81 & 0.87 \\
\hline $\mathbf{2 0 0 6}$ & 13.59 & 12.81 & 0.78 \\
\hline $\mathbf{2 0 0 8}$ & 13.54 & 12.81 & 0.73 \\
\hline $\mathbf{2 0 0 4}$ & 13.40 & 12.81 & 0.59 \\
\hline
\end{tabular}

\section{CONCLUSION}

Climate change in Turkey has manifested itself as temperature changes and lower amounts of precipitation. Coupled with the changes in $\mathrm{CO} 2$ concentrations, these developments have implications for crop and livestock productivity. The effect of climate change on production varies by crop. Yield effects vary with region. Yield improvement at higher latitudes has been found fairly consistently. On the other hand, crop yields in warmer, low latitude and semi-arid areas like the US South and Southwest often are found to be reduced by climate change. The analogy may be extended to Turkey. If the climate changes, yields can generally be enhanced by producer adaptations, aided by education and government programs.

Farmers may adapt by changing planting dates, substituting cultivars or crops, changing irrigation practices, and changing land allocations among crop production, pasture, and other uses [10].

Risk perceptions and disaster management planning for agriculture sector should be made to include these concerns. Long term climate trends should be made known to producers.
Government programs that involve open space protection, tax policy and land use planning in the agricultural sector should involve issues of climate change.

\section{REFERENCES}

[1] J. F. McEldowney and S. McEldowney, Environment and Law: An Introduction for Environmental Scientists and Lawyers, Longman, London, p. 261, 1996.

[2] Ministry of Environment and Forestry. (2008). Climate Change and the Ongoing Studies. [Online]. Available: http://www.dsi.gov.tr/docs/iklimdegisikligi/iklim_degisikligi_ve_yap \%C4\%B1lan_calismalar_ekim_2008.pdf?sfvrsn=2

[3] OECD, Economic Aspects of Adaptation to Climate Change, Costs, Benefits and Policy Instruments, p. 43, 2008.

[4] IPCC, Climate Change 2007: Mitigating the Effects of Climate Change, Contribution of Working Group III to the Fourth Assessment Report of the Intergovernmental Panel on Climate Change, Cambridge University Press, Cambridge, pp. 717-743, 2007.

[5] IPCC, Climate Change 2007: Impacts, Adaptation and Vulnerability, chapter 17, Cambridge University Press, Cambridge, pp. 717-743, 2007.

[6] A. Atalık. (2011). Global warming and its effects on water resources and agriculture. [Online]. Available: http://www.zmo.org.tr/resimler/ekler/ce6d3c8830d27ec_ek.pdf

[7] FAO, 2011: State of the World's Forests, Food and Agriculture Organization of the United Nations, Rome, 2011.

[8] FAO, FAO Statistics, Food and Agriculture Organization of the United Nations, Rome, 2012.

[9] S. Celik, H. Bacanll, and H. Görgec. (2008). Global warming and its effects on human health. [Online]. Available: http://www.mgm.gov.tr/files/genel/saglik/iklimdegisikligi/kureselikli mdegisikligietkileri.pdf

[10] B. McCarl and I. Dellal, "Agriculture in the climate change and energy squeeze: Effects, adaptation and mitigation," International Conference on Climate Change and Environmental Effects, Konya, pp 1-7, 2007.

[11] C. Rosenzweig and D. Hillel, Climate Change and the Global Harvest: Potential Impacts of the Greenhouse Effect on Agriculture, Oxford University Press, New York, 1998.

[12] R. Cynthia and A. Iglesias. (2006). Potential Impacts of Climate Change on World Food Supply: Data Sets from a Major Crop Modeling Study. [Online]. Available: http://sedac.ciesin.columbia.edu

[13] Cline and R. William, Global Warming and Agriculture: Impact Estimates by Country, Center for Global Development and Peterson Institute for International Economics, Washington, 2007.

[14] G. Fischer, M. Shah, and H. Velthuizen, Climate Change and Agricultural Vulnerability, IIASA, Laxenburg, Austria, 2002.

[15] FAOstat. (2014). FAOstat Domains (Land). [Online]. Available: http://faostat3.fao.org/download/R/RL/E

[16] United States Department of Agriculture. (2014). Office of the Chief Economist. [Online]. Available: http://www.usda.gov/oce/weather/pubs/Other/MWCACP/index.htm

[17] Agriculture Draft Report (2014), Turkey National Employment Strategy-2014-2023. The Ministry of Labour and Social Security, Ankara. [Online]. Available: www.uis.gov.tr/media/1093/tarım-sektoerue-raporu-15122014.docx

[18] TurkStat. (2015). [Online]. Available: http://www.turkstat.gov.tr/UstMenu.do?metod=kategorist

[19] TOBB (Turkish Union Chambers and Commodity Exchange). (2014). [Online]. Available: http://www.tobb.org.tr/Documents/yayinlar/2014/turkiye_tarim_mecl isi_sektor_raporu_2013_int.pdf

[20] Ministry of Food, Agriculture and Livestock. (2013). Data. [Online]. Available:

http://www.tarim.gov.tr/Belgeler/SagMenuVeriler/Tarimsal_Veriler.p df

[21] TSI-TurkStat (Turkish Statistical Institute-TUIK). (2012). [Online]. Available: http://www.tuik.gov.tr

[22] The Tenth Development Plan-2014-2018 (2013). Sustainable Farmland Use, Working Group Draft Report, Ankara 2014, No-2860/OIK.714. [Online]. Available: http://tarim.kalkinma.gov.tr/wpcontent/uploads/2014/12/Tarim_Arazi lerinin_Surdurulebilir_Kullanimi_Calisma_Grubu_Raporu.pdf

[23] DPT (State Planning Organization), Ninth Development Plan 2007-2013: Use and Management of Land and Water Resources and 
Special Commission Report, DPT Publication No: 2718-OIK-671, Ankara, 2007.

[24] Ministry of Food, Agriculture and Livestock. (2015). Data. [Online]. Available: http://www.tarim.gov.tr/

[25] TSI-TurkStat. (2015). [Online]. Available: http://www.tuik.gov.tr/UstMenu.do?metod=temelist

[26] P. Topcu, Policies for Conservation and Efficient Use of Agricultural Lands, DPT (State Planning Organization) Planning Master's Thesis, The Ministry of Development, Publication No: 2836, Ankara, 2012.

[27] H. Günlü, Land Consolidation Applications: Turkey, DPT (State Planning Organization) Planning Master's Thesis, Ankara, 2012.

[28] Anonymous, First National Communication on Climate Change, Ministry of Environment and Forestry, Ankara, 2007.

[29] M. Turkes, Climate Change, Drought and Desertification in the World and Turkey, 2nd National Congress on Soil and Water Resources: Proceedings, Ankara, November 22-25, 2011

[30] IPCC. (2014). Climate Change 2014 (5th Report). [Online]. Available: http://www.ipcc.ch/pdf/assessmentreport/ar5/syr/SYR_AR5_FINAL_ full.pdf

[31] NCCAP. (Turkey National Climate Change Action Plan). (2012). [Online]. Available: http://idub.csb.gov.tr/SayfaIcerik.aspx?Id=7211c8c4-a022-4c98-9560 -c1a067cabab9

[32] F. Giorgi and P. Lionello, Climate Change Projections for the Mediterranean Region, vol. 63, pp. 90-104, 2008.

[33] TSMS (Turkish State Meteorological Service). (2010). Evaluation of climate data for 2009. Ankara. [Online]. Available: http://www.mgm.gov.tr/en-us/

[34] TSMS (Turkish State Meteorological Service). (2011). Evaluation of climate data for 2010. Ankara. [Online]. Available: http://www.mgm.gov.tr/files/iklim/2010-yili-iklim-degerlendirmesi.p $\mathrm{df}$

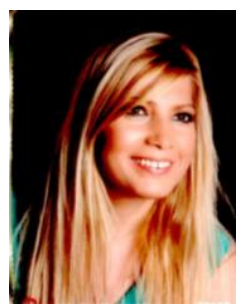

Ayse Ozcan was born in Ardahan, Turkey on July 15, 1978. She has the following degrees: a bachelor of arts in political science and public administration from the University of Inonu, Malatya (Turkey) in 2001; a masters degree in public administration with a thesis titled "housing policy of Turkey" from the Inonu University, Malatya (Turkey) in 2004; and a Ph.D. in division of urbanization and environmental problems, Public Administration from the University of Inonu,
Malatya (Turkey) in 2008

She is a professor at the Department of Political Science and Public Administration, and she is currently the head of the Department of Politica Science and Public Administration at the Giresun University. She has taught at Inonu University and Giresun University. Her latest publication is about "Environmental impact assessment (EIA) in protected areas of turkey and sustainability dilemma: The case of national parks," (with Eric Strauss) Sustainable Environment and Agriculture IPCBEE, vol. 76, 2014, pp. 82-88. Her current research interests include ecological planning, urban planning policies, urban regeneration, environmental management, climate change and agricultural policies. She has specialized in evaluating the application of legal principles to urban and environment policies.

Dr. Ozcan is a consultant of Giresun Chamber of Commerce and Industry and a member of the TOBB (The Union of Chambers and Commodity Exchanges of Turkey). She is the province representative of the TEMA Foundation in Giresun. She has been a tubitak (Turkish National Science Foundation) referee for 1001 projects (2013 and 2014)

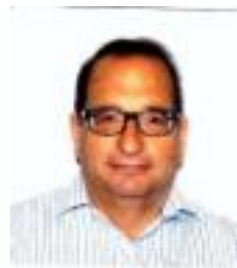

Eric J. Strauss was born in Chicago, Illinois, U.S.A. on April 14, 1947. He holds the following degrees: a bachelor of arts in political science from the University of Wisconsin-Madison, Madison, Wisconsin (U.S.A.) in 1968; a juris doctor in law from Northwestern University, Chicago, Illinois (U.S.A.) in 1971; and a Ph.D. in urban and regional planning from the University of Wisconsin-Madison,

Madison-Wisconsin (U.S.A.) in 1980

He has been the program chairman of the Graduate Program in Urban Planning at the University of Kansas, Chairman of the Department of Urban Planning at Jackson State University. $\mathrm{He}$ has taught at Indiana University-Bloomington, Queen's University (Belfast, Northern Ireland), Dortmund University (Germany) and Babes-Bolyai University (Romania). $\mathrm{He}$ is currently the director of master's programs, School of Planning, Design and Construction, Michigan State University, East Lansing, Michigan (U.S.A.). He has specialized in evaluating the application of legal principles to urban planning policy choices.

Dr. Strauss is a member of the Academic Advisory Council for Signage Research and Education (A.A.C.S.R.E.), the American Institute of Certified Planners (A.I.C.P.) and the State Bar of Kansas. He has been a Fulbright Specialist to Panama City, Panama. 